\title{
An Industry Without Industrialization: The Political Economy of The Failure of Indonesia's Auto Industry
}

\author{
Wan-Ping Tai Chen Shiu University, Taiwan
}

\begin{abstract}
The development of auto industry needs a series of related policies and conditions, including market, technology, management, basic infrastructure, etc. Several Southeast Asian countries are hoping to develop their auto industries in order to lead the development of other industries in their countries. Having the largest auto market in Southeast Asia, Indonesia is supposed to have more favorable conditions than Thailand and Malaysia on the development of auto industry. Unlike Malaysia's auto industry that has its own national brand, Indonesia does not have a national auto brand, nor like Thailand as the largest auto exporting country in Southeast Asia, a Japanese scholar even contends that Indonesia's auto industry is "technology-less industrialization".Based on the above analysis, the paper argues that the failure of Indonesia's auto industry has to do with the structural factors in Indonesia's political economy. This paper therefore will, by taking the perspective of political economy, explore the following four factors over the failure of Indonesia's auto industry: (1) inappropriate state intervention, (2) distorted government-business relations, (3) failure to join international complementarities in the auto industry, and (4) ineffective management on globalization.
\end{abstract}

Keywords: Indonesia's Political Economics, Automobile Industry, State Intervention, Government-Business Relations, Transnational Industry, Industry Globalization

\section{Introduction}

The development of auto industry needs a series of related policies and conditions, including market, technology, management, basic infrastructure, etc. Several Southeast Asian countries are hoping to develop their auto industries in order to lead the development of other industries in their countries. The turnout may vary, however, depending on different development strategies and the ecology of political economy in each country (Jenkins, 1987 and 1995; Doner, 1991).

Thailand and Malaysia started their auto industries in the 1960s, establishing a base for auto assembly. Malaysia, however, pushed for a "national auto brand project" in 1982, one year after Mr. Mahathir bin Mohamad was sworn in as Malaysia's new Prime Minister in 1981. Proton BHD(Perusahaan OtomobilNasional), a 
national auto company was then established, starting a new era of the auto industry in Malaysia. The Malaysia state then began to take a more active role (investor and producer) in the auto industry. Under the protection of a series of state policies, Proton BHD began to dominate domestic auto industry in Malaysia, and began to export Malaysiamade autos to the international market since 1989. At the peak period, Proton BHD, the only national auto in Southeast Asia, once had assets of MYR 4.6 billion, ${ }^{1}$ including 350 chain factories supplying more 6,000 auto parts, and 30,000 employees (Tseng 2001: 17-22).

Unlike Malaysia state-dominated auto industry, auto industry in Thailand is dominated by private sectors, particularly since the late 1980s. The Thailand government provided a series of favorable policies for multinational corporations to establish auto manufacturing base in Thailand, while domestic capital were encouraged to make investment on producing auto parts.

Due to this corporation between multinational corporations and domestic capital, Thailand's auto industry is becoming more competitive in the world market. When Mr. ThaksinShinawatra became Thailand's Prime Minister in 2001, he further promoted a strategy of exporting autos to the world market in 2002. As a result, Thailand, since 2005, has produced more than 1.12 million autos annually, becoming the largest auto producing center. This has made Thailand to win the reputation of "Asia's Detroit".

As compared with the auto industries in Malaysia and Thailand, Indonesia actually was the first Southeast Asian country to start its auto industry from an investment by General Motor on an auto assembly

\footnotetext{
${ }^{1}$ The exchange rate between one American dollar and
} Malaysia Ringgit (MYR) is roughly 1: 2.97 in 2010. factory in 1929. Due to the auto expansion in Indonesia, the demand of auto assembly gradually increased since the early 1940s, playing a leading role in Indonesia's national industries.

Since Indonesia's independence in 1945, Indonesian leaders gradually realized the importance of developing local capital in order to avoid greater dependence on foreign capital (Feith, 1962). With the implementation of guided democracy and guided economy, the Sukarno government then made the state apparatus to direct the auto industry through the promotion of economic nationalism and localization (Pribumi) since the mid-1950s. As state enterprises were expanding, national capital was playing a dominant role for Indonesia's domestic industrialization (Soong 1996: 279282). Auto industry then became a significant indicator showing the growth of economic nationalism in the Muslim state.

When Mr. Suharto took power in 1966, Indonesia established the Bureau of National Planning and Development (Bappenas) in charge of economic development policies, which initiated a new strategy to introduce more foreign capital for auto assembly factories (Ito 2002). When the first oil crisis took place in 1973, the rising oil price benefited oil-producing Indonesia, thus generating huge foreign reserve that is attractive for more foreign investment to the auto industry. With more than 20 auto assembly factories for more than 50 auto brands, Indonesia's auto production grew by $5 \%-6 \%$ annually in the first part of the 1970s (Aminullah and Adnan 2010: 119-120).

As foreign capital kept coming to Indonesia, domestic enterprises were provoked, causing an anti-Japanese riot when former Prime Minister Kakuei Tanaka visited Jakarta in 1974 (Chalmers 1994). President Suharto then reviewed and proposed a series of Indonesia's industrial policy, including a requirement for foreign 
investment to establish "joint ventures" with local enterprises, owing $51 \%$ of assets for local enterprises after a certain period of time, forbidding foreign investment on certain industries, and regulating the number of foreign employees (Pangestu and Habir 1989: 224-241). Accordingly, state capital was gradually accumulated by way of promoting the development of domestic enterprises, economic nationalism then once again became a major ideology in Indonesia (Soesastro 1989: 105-117; MacIntyre 1991: 369-395). This was the general scenario of the auto industry in Indonesia during the 1980s.

The Suharto government continued this protective policy on the auto industry in the 1990s; President Suharto even initiated, in1996, a "Pioneer project" to promote producing autos with a national brand. ( $\mathrm{Wu}$ 2011:52) Japan and the United States were not satisfied with Indonesia's subsidy policies to the auto industry, they accused of Indonesia to the World Trade Organization (WTO) by violating free trade rules under the WTO framework. Indonesia lost this legal case in the WTO in 1997, which forced the Muslim country to give up its protective policy to the auto industry.

After the 1997 Asian financial crisis, Indonesia was forced to move towards free market economy policy, opening the door for foreign capital into the auto industry in Indonesia. Due to previous connections and related financial and insurance companies in Indonesia, Japanese auto producers benefited from this free market policy by taking $90 \%$ of the auto market in Indonesia (Nag, Banerjee and Chatterjee 2007: 26). Given the increasing foreign investment, Indonesia's auto industry, unfortunately, failed to improve its knowledge and technology about auto manufacturing, continuing to rely upon imported auto parts.
Figure 1 shows Indonesia's vacillating policy over the development of the auto industry. Figure 2 also shows the ups and downs of auto production in Indonesia during the 1970s, 1980s, and 1990s, a result of the irresolute policies on the auto industry, as argued by HaryoAswicahyono. (Aswicahyono, Bird, and Hill).

Having the largest auto market in Southeast Asia, Indonesia is supposed to have more favorable conditions than Thailand and Malaysia on the development of auto industry (Chalmers 1994). However, unlike Malaysia's auto industry that has its own national brand, Indonesia does not have a national auto brand. Nor like Thailand as the largest auto exporting country in Southeast Asia, Indonesia only took $0.9 \%$ of auto production in the world market in 2010, as shown in Table 1.

Due to the low quality of the auto industry, Indonesia's auto industry falls far behind the level of auto industries in Thailand and Malaysia, becoming completely knocked-down (Aswicahyono 2003).

A Japanese scholar even contends that Indonesia's auto industry is "technologyless industrialization", (Yoshihara 1998) making Indonesia's auto industry "having market without technology" or "an industry without industrialization."

Based on the above analysis, the paper argues that the failure of Indonesia's auto industry has to do with the structural factors in Indonesia's political economy. This paper therefore will, by taking the perspective of political economy, explore the following four factors over the failure of Indonesia's auto industry: (1) inappropriate state intervention, (2) distorted government-business relations, (3) failure to join international complementarities in the auto industry, and (4) ineffective management on globalization. 


\section{Figure 1. Indonesia's Irresolute Policies over the Auto Industry}

Source: Authors.

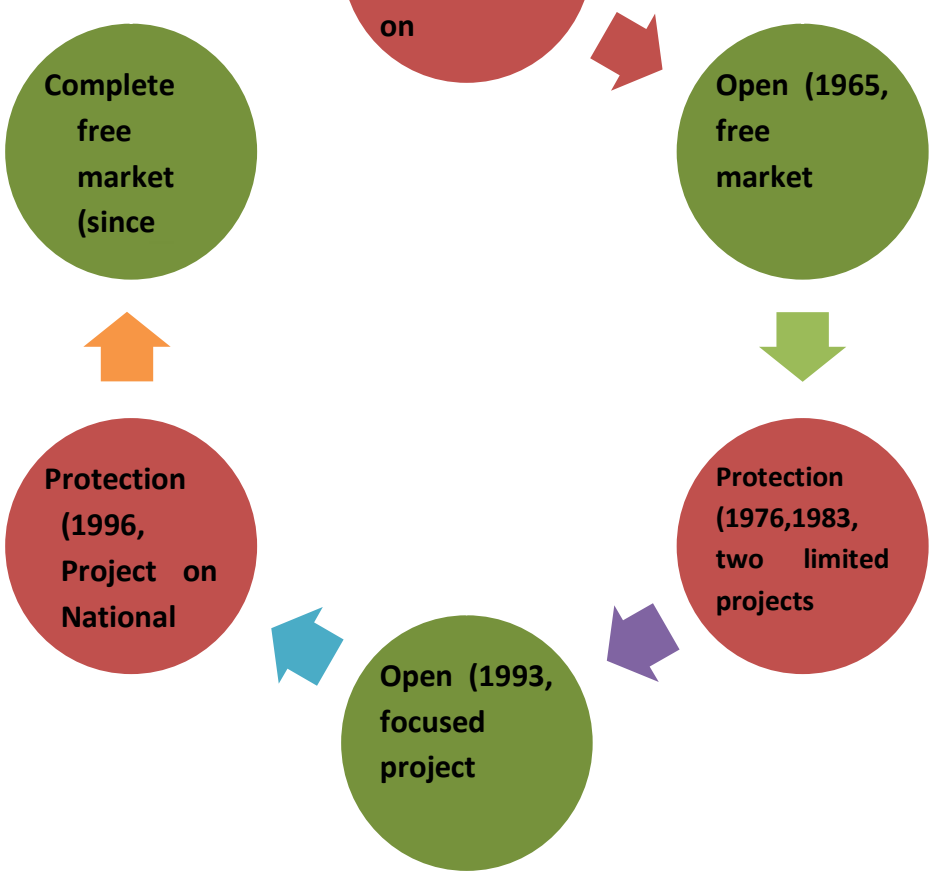

Table1. Auto Production in Three Southeast Asian Countries and their share in the world auto market (1999-2010)

\begin{tabular}{|c|c|c|c|c|c|c|c|c|c|c|c|c|}
\hline & \multicolumn{2}{|c|}{1999} & \multicolumn{2}{|c|}{2000} & \multicolumn{2}{|c|}{2005} & \multicolumn{2}{|c|}{2008} & \multicolumn{2}{|c|}{2009} & \multicolumn{2}{|c|}{2010} \\
\hline $\begin{array}{c}\text { Production } \\
\text { Countries }\end{array}$ & Production & $\begin{array}{c}\text { Share of } \\
\text { world } \\
\text { market } \\
(\%)\end{array}$ & Production & $\begin{array}{c}\text { Share } \\
\text { of } \\
\text { world } \\
\text { market } \\
(\%) \\
\end{array}$ & Production & $\begin{array}{c}\text { Share } \\
\text { of } \\
\text { world } \\
\text { market } \\
(\%)\end{array}$ & $\mid \begin{array}{c}\text { Productio } \\
\mathrm{n}\end{array}$ & $\begin{array}{c}\text { Share of } \\
\text { world } \\
\text { market } \\
(\%)\end{array}$ & Production & $\begin{array}{c}\text { Share of } \\
\text { world } \\
\text { market } \\
(\%)\end{array}$ & Production & $\begin{array}{c}\text { Share } \\
\text { of } \\
\text { world } \\
\text { market } \\
(\%)\end{array}$ \\
\hline Indonesia & 89,007 & 0.16 & 292,710 & 0.50 & 500,710 & 0.75 & 600,628 & 0.85 & 464,816 & 0.75 & 702,508 & 0.90 \\
\hline Malaysia & 254,090 & 0.45 & 282,830 & 0.48 & 563,408 & 0.85 & 530,810 & 0.75 & 489,269 & 0.79 & 567,715 & 0.73 \\
\hline Thailand & 322,761 & 0.57 & 411,721 & 0.71 & $1,122,712$ & 1.69 & 1,393742 & 1.98 & 999,378 & 1.62 & $1,644,513$ & 2.12 \\
\hline
\end{tabular}

Source: http://oica.net/category/production-statistics/2009-statistics/ accessed 1July 2012. 
Figure 2.Indonesia's economic growth rates, industrial policies, and auto production (1976-1997)

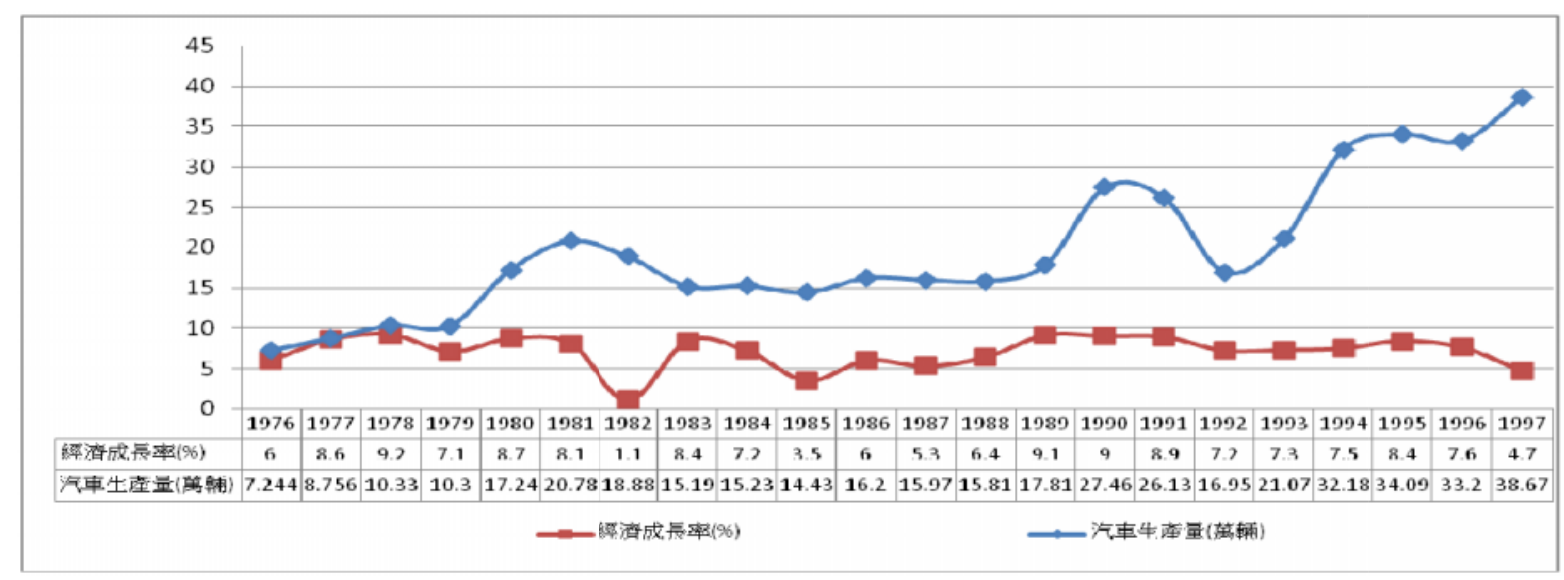

Inappropriate State Intervention

According to the theory of developmental state, developing countries are likely to use state apparatus to intervene the market, in support of the development of selective industries (Johnson, 1982). Taking the South Korean example, Dr. P. Hanson argues that state intervention has played a key role for the successful economic development in East Asian countries (Hanson, 1976). Based on the approach of developmental state, Alice Amsden shares similar point view with Hanson (Amsden 1989).

These scholars contend that weak market institutions in these countries have given a leeway for state intervention (Johnson 1987: 136-164). Although there are other theories, such as protecting infant industry (Gerschenkron, 1962) and governed market theory (Wade, 1990), to support the policy of state intervention, most scholars agree that state intervention is necessary to maintain economic stability and national capital accumulation in the developing countries (MacIntyre 1993: 123164).
The case of Thailand implies that state intervention over industrial policy is possible only when state apparatus is strong enough; weak states, on the contrary, usually take a freer industrial policy (Abbott 2003: 113). Indonesia and Malaysia are termed in the category of "strong states", because they both have taken strong state intervention over the auto industries in their countries. In Malaysia, the Malays have long ruled the political system that dominates the design of industrial policies.

The Malay-predominated Malaysia has a very clear goal on the development of the auto industry, i.e. establishing an auto industry with a national brand, which is equipped with other related trade and industrial policies (Crouch 1993: 133-158). The Malaysian government has then designed a series of protective policies over the auto industry, including easy access to obtain national capital, immune on import tax, efficient permit application, etc (Tai 2008: 53-76). One scholar even said that the Malaysian government has "the will to develop" the auto industry, i.e. using state intervention policy to make Malaysia-made 
autos popular in the world market (Chu 2011: 248).

While embracing free trade based on classic economic theory, Thailand takes the most open policy on the auto industry in Southeast Asia. Due to long rule under military authoritarianism, Thailand is supposed to have a strong state, but state apparatus is actually quite weak in Thailand due to a number of factors such as frequent military coups, elite-dominated political economy, etc. As a result, private sectors were able to play a dominant role in the decision making process of industrial policies, making Thailand become a "weak state, strong society". This is why Thailand has taken an open and free industrial policy for some years.

Indonesia's policies to the auto industry are indecisive, however, in spite of its statecentered policies over industrial development. In addition to industrial factors, Indonesia's auto industry actually involves political choices (Aminulla and Adnan 2010: 111-168).

Since its independence in 1945, economic nationalism has become a major ideology in Indonesia's industrial development, similar to what R. Robison called "Bureaucratic capitalism" Robison 1998: 113 $\square$ With the prevalence of bureaucratic capitalism, native capital is not able to compete with national capital; Indonesia government then is able to use state apparatus to adjust the structure between national capital and local capital.

The auto industry, therefore, becomes an important tool to implement economic nationalism (Jomo 2007: 497).When Mr. Suharto took power in 1967, he followed the footsteps of Mr. Sukarno. Professor William Liddle contends that Suhato's New Order government often took Indonesia's development strategy for political purposes (Liddle 1987: 143). This is why Indonesia's policies over the auto industry were swinging back and forth between free market policy and protective policy in the last four or five decades.

Due to the influence of these two entangled factors, Indonesia's auto industry has been troubled with a number of related factors, i.e. lack of a specific development goal, irresolute industrial development strategy, lack of a package of policies for establishing an industry with a national brand, etc (Aminullah and Adnan 2010: 111168).

Simply speaking, Indonesia government is taking state intervention policy but without principles, which is what Michael Rock has termed as "priceless interventionism" (Rock 1999: 691-704). This inappropriate state intervention contributes to the failure of the auto industry in Indonesia, and a key difference over the auto industries between Indonesia and Malaysia.

\section{Distorted Government-Business Relationship}

The institutional school of political economy upholds that industrial growth comes from policy output, which is based not only economic consideration but also a rational choice after the involvement of political manipulation (Chang, 1994). There are at least the following three considerations for state intervention over industrial development: (1) Does this industrial policy meet national ideology? (2) Does national elite own the autonomy to implement this policy? (3) Does this policy benefit the ruling govenment? Some scholars even contend that state intervention over industrial policy is a tool to satisfy political interest of the ruling elite (Haggard 1997: 81-82; Jomo 2007: 497).

Accordingly, advocates of institutionalism argue that state intervention over industrial is not always successful, because of a number of factors, 
such as the indecisive nature of public goods in the policy-making process, the weakness of operation of democratic system, selfishness of government officials and representatives, the influence of interest groups, etc.

This will then result in "government failure", which, to some extent, is even worse than "market failure" (Kruger 1991: 9-23). Government failure will bring about some non-economic cost, such as deterring entrance, weakening competitive capability, etc. This is the so-called rent seeking (Buchanan 1980: 3-15) or political favoritism (Hasan and Jomo 2006: 178), which will then involve a unique government-business relationship. In a democratic and an institutionalized country, governmentbusiness connections are legally regulated, but countries like Indonesia where political system is not well institutionalized, government-business relationship is usually out of legal binding.

Therefore, the auto industry was a tool for the ruling elite to allocate political and economic resources during the Suharto authoritariansm. For example, the Indonesia Service Company (ISC) was supposed to manufacture autos in the 1950s, but actually the ISC's ruling elite, based on a distorted government-business relationship, was mainly to obtain the permit from the government to distribute auto imports licenses.

The owners of the ISC then greatly profited from this license distributing rather than from auto manufacturing. During the Suharto presidency, only six out of twentyone auto factories were doing auto manufacturing, while the rest was mainly engaged in auto imports and exports. Evidently, Indonesian auto makers were more interested in managing this unique government-business relationship, rather than doing auto manufacturing.

As these non-economic factors determined the development of the auto industry in Indonesia, other industries followed, which has become a unique structure of political economy over Indonesia's industrial development (Aswiahyono, Basri and Hill 2003: 214).

Since the early 1970s, big business corporations, having this particular government-business relationship, were able to profit from their joint ventures with Japanese auto companies, while middle and small-sized auto assembly companies, due to lack of connections with the government, were losing competitive capability and eventually dependent upon big companies(Chalmers 1996:28). As a result, Indonesia lost the opportunity to establish an industrial complementary relationship in the auto manufacturing industry, making Indonesia auto industry difficult to improve (Adan, 1998).

Furthermore, Indonesia's auto industry was actually monopolized by business tycoons during the Suharto presidency, who were either from the Suharto family or had close connections with Mr. Suharto. For Instance, Mr. Tommy Suharto, the youngest son of President Suharto, established the Timor Putra Nasional and, with the help from the Indonesian government, received, in 1997, a loan of US\$690 million for two years from four government banks and twelve private banks with low interest rates.

Under Indonesia's "pioneer project", Timor Putra then easily obtained the permit to cooperate with KIA, a South Korean auto company, which enjoyed immune on importing auto parts. The most important goal of the pioneer project was to establish a national auto brand, but Timor Putra imported KIA autos without paying taxes but covered with Timor brand. Even though Timor appears to be a native auto brand in Indonesia, it is a completely Korea-made auto, contradictory to the original goal of the pioneer project. 
Due to this distorted governmentbusiness relationship, Indonesia's auto industry is considered to be an output of costly interventionism, causing corruption and inefficiency. A number of auto tycoons have appeared in Indonesia since the 1950s, including JadjimNing who monopolized auto imports in the 1950s, William Soeryadjaya (owner of ASTRA International TBK PT) who was termed as king of the auto assembly in Indonesia, etc. Table 2 shows the the list of government-business connections in the Indonesia's auto industry.

These business tycoons monopolized auto industry through their connections with government officials, which is the second reason contributing to the failure to be industrialized in the Indonesia's auto industry.

\section{Failure to Join International Complementarities In the Auto Industry}

The school of dependency theory has often blamed multinational corporations to exploit and marginalize peripheral countries, causing underdevelopment in the Third World countries. The school of dependent dependency, however, contends a possible change for dependent countries if international factors are involved.

Accordingly, Peter Evans contends that developing countries are likely to cooperate with multinational corporations, (Evans 1979:32-54) whereas Immanuel Wallerstein has termed the involvement of multinational corporations as "development by invitation".

Peter Evans further promoted triple alliance (i.e. native government, international capital, and local capital) for the development of Third World countries, which means that development in the Third World countries is possible if these three actors work well. (Evans, 1979)
If the theory of triple alliance is applied to the auto industry in a Third World country, it means that native government helps local capital to cooperate with multinational corporations, so that local government would be able to establish its own auto industry while multinational corporations would profit from the expansion of its auto market in this specific Third World country.

Thailand actually has taken this development model and is able to become "Asian Detroit", becoming one of the bases of the auto industry in the global market. Thailand started an open industrial policy in the late 1980s, and further allowed, after the 1997 Asian financial crisis, foreign capital to take full ownership over their investment in the Buddhist country.

Accordingly, supply chain in the auto industry is established in Thailand, because local small and medium-sized companies manufacture auto parts and supply them to the foreign-owned auto assembly companies in Thailand. This is the key reson why Thailand can become a hub of auto parts in Southeast Asia. (Kohpaiboon 2007: 8) Unlike Thailand, Malaysia does not cooperate with multinational corporations, but the Malaysian government takes an active role in establishing a supply chain for its auto industry through a series of protective policies. While upholding economic nationalism, Malaysia has formulated a model of "Self-development", which has also helped the establishment of a national auto brand. 
Table 2. Government-Business connections in the Auto Industry during the New Order Period

\begin{tabular}{|c|c|c|c|c|c|c|}
\hline \multirow{2}{*}{$\begin{array}{c}\text { Business } \\
\text { corporations }\end{array}$} & \multirow{2}{*}{$\begin{array}{l}\text { Market } \\
\text { occupation }\end{array}$} & \multirow{2}{*}{$\begin{array}{c}\text { Political } \\
\text { connections }\end{array}$} & \multirow{2}{*}{ Companies } & \multirow{2}{*}{$\begin{array}{c}\text { Year } \\
\text { Established }\end{array}$} & \multicolumn{2}{|c|}{ Foreigner Partners } \\
\hline & & & & & $\begin{array}{l}\text { Managing } \\
\text { Partners }\end{array}$ & $\begin{array}{c}\text { Manufacturing } \\
\text { Contractors }\end{array}$ \\
\hline \multirow[t]{5}{*}{ Astra } & \multirow[t]{5}{*}{$50.6 \%$} & \multirow[t]{5}{*}{$\begin{array}{l}\text { Government } \\
\text { and Chinese }\end{array}$} & Toyota Astra Moto & 1972 & \multirow{5}{*}{$\begin{array}{l}\text { Toyota }(49 \%) \\
\text { ISUZU } \\
(12.5 \%) \\
\text { Daihatsu } \\
(40 \%) \\
\text { Nissan } \\
(12.5 \%)\end{array}$} & \multirow[t]{5}{*}{$\begin{array}{l}\text { Isuzu, BMW, Ford, } \\
\text { Peugeot }\end{array}$} \\
\hline & & & Gay a motor & 1955 & & \\
\hline & & & Pantja Motor & 1974 & & \\
\hline & & & Astra Daihatsu Motor & 1992 & & \\
\hline & & & $\begin{array}{l}\text { Astra Nissan Diesel } \\
\text { Indonesia }\end{array}$ & 1996 & & \\
\hline \multirow[t]{4}{*}{$\begin{array}{l}\text { Indomobil } \\
\text { (Salim) }\end{array}$} & \multirow[t]{4}{*}{$21.0 \%$} & \multirow[t]{4}{*}{ Chinese } & $\begin{array}{l}\text { Indomobil Suzuki } \\
\text { International }\end{array}$ & 1991 & \multirow[t]{4}{*}{$\begin{array}{l}\text { Suzuki }(49 \%) \\
\text { Nissan }(35 \%)\end{array}$} & \multirow{4}{*}{$\begin{array}{l}\text { Audi, Volvo, } \\
\text { Ssangyong } \\
\text { Mazda, Volvo, VW, } \\
\text { Audi, Nissan, } \\
\text { Chrysler }\end{array}$} \\
\hline & & & $\begin{array}{l}\text { Ismac Nissan } \\
\text { Manufacturing }\end{array}$ & $\begin{array}{l}1996 \\
1973\end{array}$ & & \\
\hline & & & Ismac & 1973 & & \\
\hline & & & $\begin{array}{l}\text { Hino Automobil } \\
\text { Indonesia }\end{array}$ & & & \\
\hline \multirow[t]{2}{*}{ KramaYudha } & \multirow[t]{2}{*}{$18.1 \%$} & \multirow[t]{2}{*}{$\begin{array}{l}\text { Native } \\
\text { corporations }\end{array}$} & $\begin{array}{l}\text { KramaYudhaKesuma } \\
\text { Motor }\end{array}$ & 1981 & \multirow[t]{2}{*}{ Hino $(39 \%)$} & \\
\hline & & & $\begin{array}{l}\text { KramaYudhaRatu } \\
\text { Motor }\end{array}$ & 1975 & & \\
\hline Imora & $1.8 \%$ & Chinese & Honda Prospect Motor & 1995 & $\begin{array}{l}\text { Mitsubishi } \\
\text { KramaYudha } \\
\text { Motors }\end{array}$ & Mitsubishi \\
\hline Bimantara & $1.0 \%$ & $\begin{array}{l}\text { The Suharto } \\
\text { family }\end{array}$ & $\begin{array}{ll}\text { (a) } & \text { TricitraKarya } \\
\text { (b) } & \text { BimantaraHyndai } \\
& \text { Indonesia } \\
\end{array}$ & 1995 & Honda $(49 \%)$ & $\begin{array}{l}\text { Hyundai } \\
\text { Ford }\end{array}$ \\
\hline Starsauto & $0.2 \%$ & $\begin{array}{l}\text { The Suharto } \\
\text { family }\end{array}$ & StarsautoDinamika & 1995 & $\begin{array}{l}\text { Hyundai } \\
(50 \%)\end{array}$ & Daewoo \\
\hline Humpus & $5.0 \%$ & $\begin{array}{l}\text { The Suharto } \\
\text { family }\end{array}$ & Kia-Timor Nasional & 1998 & $\begin{array}{l}\text { Hyundai } \\
(30 \%)\end{array}$ & \\
\hline $\begin{array}{l}\text { Mercedes } \\
\text { Benz }\end{array}$ & $1.3 \%$ & Germany & $\begin{array}{l}\text { Mercedes-Benz Group } \\
\text { Indonesia }\end{array}$ & 1970 & $\begin{array}{l}\text { Daimler } \\
\text { Chrysler } \\
(95 \%)\end{array}$ & \\
\hline GM & $1.1 \%$ & U.S.A & GM Buana Indonesia & 1994 & GM (100\%) & $\begin{array}{l}{ }^{*} \text { wholly owned by } \\
\text { GM in } 1997\end{array}$ \\
\hline
\end{tabular}

Indonesia, however, is neither taking the Thailand model nor the Malaysian 
model, due to its indecisive policies to the auto industry no matter it be President Sukarno or President Suharto. According the Japan Automobile Manufacturing Association (JAMA), Indonesia, as compared with Thailand and Malaysia, received the least technology transfer and human resources training programs from Japan, in spite of Japan being the largest auto investor in these three Southeast Asian countries, as shown in Table 3. (Soejachmoen 2011:19)
Table 4 shows that foreign owned companies, mostly Japanese companies $(46.9 \%)$, dominated the production of auto parts in Indonesia. Table 5 shows that the level of technology in the Indonesia's auto industry is very low, playing a limited role on "Brand to Brand Complementation" in Southeast Asia. (Fujita and Hill 1997: 317) Some scholars even criticized that Indonesia's auto industry only shares a tiny part of the profits in the cross-country complementarities while foreign owned companies enjoy a huge portion of the profits.

Table 3. Japan's technology transfer and human resources training programs in Southeast Asia since 2005

\begin{tabular}{|c|l|l|}
\hline Year & \multicolumn{1}{|c|}{$\begin{array}{c}\text { Technology } \\
\text { Transfer }\end{array}$} & \multicolumn{1}{|c|}{ Human Resources Training Programs } \\
\hline 2005 & & Toyota (Thailand) \\
\hline 2006 & & Nissan (all Southeast Asian countries) \\
\hline 2007 & $\begin{array}{l}\text { Honda } \\
\text { (Philippines) } \\
\text { Nissan } \\
\text { (Thailand) }\end{array}$ & Honda(Malaysia) \\
\hline 2008 & $\begin{array}{l}\text { Mitsubishi(Mal } \\
\text { aysia) }\end{array}$ & $\begin{array}{l}\text { Nissan (Indonesia, Malaysia, Singapore) } \\
\text { Fuji Heavy Industries (Singapore) }\end{array}$ \\
\hline 2009 & & Toyota (Thailand) \\
\hline 2010 & $\begin{array}{l}\text { Isuzu } \\
\text { (Thailand) }\end{array}$ & Nisaan (Indonesia) \\
\hline & & \\
\hline
\end{tabular}

Source: calculated fromhttp://www.jama-english.jp/asia/publications/index.html , accessed 31 August 2012. 


\begin{tabular}{|c|c|c|c|}
\hline & Indonesia & Thailand & Malaysia \\
\hline $\begin{array}{l}\text { Number of factores } \\
\text { of } \\
\text { manufacturing } \\
\text { auto parts }\end{array}$ & 200 & 800 & 250 \\
\hline $\begin{array}{l}\text { Percentage of } \\
\text { Japanese owned } \\
\text { companies }\end{array}$ & $\begin{array}{c}82 \\
(46.9 \%)\end{array}$ & $\begin{array}{c}209 \\
(27 \%)\end{array}$ & $\begin{array}{c}61(27.1 \% \\
)\end{array}$ \\
\hline $\begin{array}{l}\text { Percentage of } \\
\text { Europe and } \\
\text { America owned } \\
\text { companies }\end{array}$ & $\begin{array}{c}7 \\
(4 \%)\end{array}$ & $\begin{array}{c}21 \\
(2.7 \%)\end{array}$ & $\begin{array}{c}19 \\
(8.4 \%)\end{array}$ \\
\hline $\begin{array}{l}\text { Patterns of foreign } \\
\text { investments } *\end{array}$ & $\begin{array}{l}\text { Exports, } \\
\text { Contracted out, } \\
\text { Holding minority } \\
\text { stocks, and joint } \\
\text { ventures }\end{array}$ & $\begin{array}{l}\text { Branch } \\
\text { companies } \\
\text { ' } \\
\text { Strategic } \\
\text { alliance, } \\
\text { and joint } \\
\text { ventures }\end{array}$ & $\begin{array}{r}\text { Strategic } \\
\text { alliance }\end{array}$ \\
\hline
\end{tabular}

Source: Calculated from Keiko Ito, Foreign Ownership and Productivity in the Indonesia Automotive Industry: Evidence from Establishment Data for 1990-1999, Working Paper Series, Vol. 2002-25, 2002, The International Center for the Study of East Asian Development, Kitayushu, p. 37. Patterns of foreign investmentsare from (Booz Allen:" Hamilton, http//:www.boozallen.com, accessed 1 September 2012.

Table 5. Industrial complementarities of the Auto Industries under the Project of "Brand to Brand Compensation" in Southeast Asia

\begin{tabular}{|l|l|l|l|l|}
\hline & Toyota & Nissan & Honda & Mitsubishi \\
\hline Thailand & $\begin{array}{l}\text { Diesel } \\
\text { engines, } \\
\text { floor }\end{array}$ & $\begin{array}{l}\text { Large panel, } \\
\text { Interior trim }\end{array}$ & Stamping & $\begin{array}{l}\text { Pump, } \\
\text { Intake } \\
\text { manifold }\end{array}$ \\
\hline $\begin{array}{l}\text { Philippine } \\
\text { s }\end{array}$ & Transmission & $\begin{array}{l}\text { Medium-sized } \\
\text { panel }\end{array}$ & $\begin{array}{l}\text { Intake } \\
\text { manifold }\end{array}$ & Transmission \\
\hline Malaysia & $\begin{array}{l}\text { Brakes, } \\
\text { Shock } \\
\text { absorbers }\end{array}$ & $\begin{array}{l}\text { Brakes, } \\
\text { Medium-sized } \\
\text { panel }\end{array}$ & Pump & $\begin{array}{l}\text { Door panel, } \\
\text { Brakes }\end{array}$ \\
\hline Indonesia & 5K Engines & None & $\begin{array}{l}\text { Engine, back } \\
\text { plate }\end{array}$ & None \\
\hline
\end{tabular}

Source: Kuniko Fujita and Richard Child Hill, "Auto Industrialization in Southeast Asia: National Strategies and Local Development", ASEAN Economic Bulletin, Vol. 13, No. 3, MARCH 1997, pp. 317. 
Due to this structural factors, Indonesia's auto manufacturers are focused on building up a special political relationship with ruling elites, in order to take a part and profit from the auto supply chain in the cross-country auto complementarities (Chalmers 1994: 25; Dorner 1991: 73-79).

One Japanese scholar says, unlike industrialization of the auto industries in Taiwan and South Korea which obtain technology and management from their cooperation with advanced multilateral corporations, Indonesia's auto tycoons, or auto godfathers, only make efforts to ensure their companies to be included in the government protective policies, rather than to cooperate with foreign companies for technology transfer and management (Chalmers 1994:25).

For example, Astra, through its particular political connections with the Suharto government, obtained a permit of establishing auto assembly companies with Toyota, but, Astra took advantage from its joint venture with Toyota to monopolize Indonesia's auto industry, instead of making efforts to upgrade the level of auto manufacturing in Indonesia.

Simply speaking, Indonesia's local auto tycoons made use of their political connections to obtain government protection in exchange for cooperation with foreign companies, whereas multinational corporations took use of local tycoons to gain an easy access to expand their auto market in Indonesia.

In this way, Indonesia's local auto dealers are to purchase auto parts from foreign companies for auto assembly in Indonesia. Accordingly, both local auto tycoons and multinational corporations profit, but Indonesia's auto industry remains unchanged; the Islam State continues to rely up the imports of auto parts, failing to reach the goal of establishing a localized auto parts manufacturing in Indonesia (Aswicahyono 1999:200).

This development model deviates far from the model of triple alliance, because local companies, under the protection of state intervention, are making efforts in building up a special government-business relationship in favor of their own interest, rather than learning technology transfer and management from foreign companies. Similarly, multinational corporations, under the umbrella of the linkage with local companies, are aimed to avoid state regulations on the imports of auto parts, rather than building up a triple alliance for the development of the auto industry in Indonesia (Doner: 1991).

Due to the absence of a real partnership between multinational corporations and local enterprises, Indonesia's auto tycoons are even being described as "supplements" for assisting foreign corporations to gain profits (Nag, Banerjee and Chatterjee 2007).

\section{Ineffective Management on Globalization}

Globalization and its effect on global industrial environment are hot issues for decades, particularly the pressure of free trade under the WTO framework. While upholding the ideology of cooperation in Southeast Asia, cooperation in the auto industry takes the major portion of industrial cooperation among the ASEAN member countries. ${ }^{2}$

Free trade and cooperation on technology can bring about a series of

\footnotetext{
2 In the $10^{\text {th }}$ ASEAN Summit in November 2004, ASEAN countries signed the ASEAN Framework Agreement for the Integration of Priority Sectors, from which the Roadmap for Integration of Automotive Products Sector was reached among member countries. Based on the Roadmap, ASEAN countries hope to reach the following goals for the auto industries in Southeast Asia, including CBU tariff elimination, effective favorable tax policy, non-tariff measures, customs cooperation, standards and conformance, future investment, improving distribution system, etc. For details, see Nenham 2006: 8)
} 
positive effects to the auto industry, including reducing manufacturing cost on auto parts, upgrading the level of auto parts production, and expanding overseas market of auto parts.

However, free trade and technological cooperation could also generate impacts over the auto industry, such as facing competition from the global market, openness of manufacturing and market, industrial repositioning, improvement on efficiency, etc.

R.H. Wade has pointed out that economic globalization has changed global industrial environment, making developing countries to experience new challenges. As economic liberalization and free market have reduced protective policies and state intervention, developing countries are required to propose different industrial strategies and capabilities for their economic development (Wade 2003: 621644).

Indonesia's auto industry, for example, is facing at least the following three challenges with the prevalence of globalization: (1) opening up domestic market after the loss of the WTO legal case, (2) freeing the auto industry to meet the IMF requirements in exchange for obtaining financial assistance from the IMF, and (3) reducing tariff under the ASEAN Industrial Cooperation Project (Nag, Banerjee, and Chatterjee, 2007: 26-41).

Due to these three challenges, Indonesia has, since 2002, given up all protective policies over its auto industry, the first country in Southeast Asia to completely reduce taxes on importing autos. As comparing with Thailand and Malaysia, these two countries have taken different approaches to face the challenges of globalization. While Thailand takes incremental steps to open up its auto market, Malaysia delays its open-door policy for the auto industry.
According to theories of political economy, developing countries, after regime transitions from authoritarianism to democracy, are likely to engage selfadjusting industrial policies and accept supervision from public and interest groups, laying a foundation for market openness and industrial transition (Chu 2001: 67-117).

Thailand has presented itself as a good example. Unlike Thailand, Indonesia did receive much foreign investment, but it did not upgrade the technology and knowledge of manufacturing autos. The key reason is because of Indonesia's continual dependence on the imports of auto parts. Thailand keeps self-adjusting its industrial policies to face the rising globalization, whereas Indonesia was forced to adjust its policies under external pressure. This is the fourth and final reason for the failure of Indonesia's auto industry.

\section{Conclusion}

This paper has compared development models of the auto industries in three Southeast Asian countries. In a weak state like Thailand, multinational auto corporations, after obtaining a permit from the Thai government, established auto assemble factories and helped local auto companies to build up auto parts manufacturing.

The triple alliance is then created among the state, multinational corporations, and local capital, and, under this framework, multinational corporations assisted Thailand's native auto industries to join international complementarities in the global auto market. As Thailand has gradually become a part of supply chain in the global auto market, Thailand is able to expand its native auto manufacturing industry. This is why Thailand has been 
termed as the Asian Detroit, a successful case of dependent development.

Being a strong state, the Malaysian government, instead of multinational corporations, dominates the auto industry, with a very clear goal under the guidance of economic nationalism (Doner, 1991).

In order to establish a national auto brand, the Malaysian government proposed a series of protective policies to accomplish this goal, including easy getting imports permit, tariff protection, making use of national capital, etc.

Similar to Malaysia, Indonesia was also under a strong state, trying to take state intervention to establish a national auto brand during the presidencies of $\mathrm{Mr}$. Sukarno and Mr. Suharto. Indonesia, however, failed to accomplish this goal, because of a series of indecisive policies, and, most importantly, a particular government-business relationship in the structure of political economy.

The case of Indonesia's auto industry has revealed that ruling elite misused statedominated auto industry for resources distribution. Due to the particular structure of government-business relationship, Indonesia's policy of state intervention failed to learn how to manage the auto market and how to become a part of supply chain in the global automobile industry, making the status of auto tycoons unchanged in Indonesia.

The state apparatus then lost the opportunities to establish a partnership relationship with multinational corporations, thus failing to make technology transferring. When globalization began to prevail since the early 1990s, Indonesia was forced to open its auto market under external pressure, making Indonesia even more difficult to establish an independent auto industry.

In their book, entitled Why Nations Fail: The Origins of Power, Prosperity, and Poverty, DaronAcemogl and James A. Robinson contend that economic prosperity in one country is dependent upon the political and economic policies that this country takes; the failure of nation-states results from the designated economic policies that are usually in favor of those who are in power, and the entire society will pay the price for the failure of nation-states. (Acemoglu and Robinson, 2012)

This study has also found out that as state intervenes industrial development, it will manipulate and misplace interest distribution. Once the network of a particular interest group is established from this distorted distribution, it takes time to remove or make a change of it. Having a huge market and with a great potential for the development of the auto industry, Indonesia, unfortunately, misused auto tycoons in the auto industry due to its particular structure of government-business connections. No wonder even $\mathrm{Mr}$. RizwanAlamsjah, deputy chairman of Indonesia Auto Manufacturing Association, is disappointed when he was asked about the future development of the auto industry in the Muslim country (Budiartie and Primartantyo, 2012).

\section{About Author}

Dr. Wan-Ping Tai is currently an associate professor and director of Foreign Affairs at Cheng Shiu University, Kaohsiung Taiwan (R.O.C.). He obtained his Bachelor degree in Public Administration and Policy at the National Taipei University, and the social science of Master degree and Doctor of Philosophy in Asia Pacific Political Economy studies at the National Sun Yat-sen University.

His primary area of study includes the following but not limited to: Southeast Asian studies, Asia Pacific studies, Indonesia studies, and Taiwan's Trade and Economics. He can be contacted at wanping.tai@gmail.com 


\section{References}

Abbott, J. P., Developmentalism and Dependency in Southeast Asia: The Case of the Automotive Industry(NY: Curzon Press, 2003), p.113.

Abdullah, R., "Business Response to the Regional Demands and Opportunity: A Study of Malaysian Automobile Industry", paper presented at Global Issues and Challenges in Business and Economics organized by Department of Management and Marketing at Corus Paradise Resort, Port Dickson. 13/12/2006-15/12/2006.

Acemoglu, D. and Robinson, James A., Why Nations Fail: The Origins of Power, Prosperity, and Poverty(New York: Crown Business, 2012).

Adnan, R. S., The Shifting Patronage, the Dynamic Relationship between Business and Government in Automotive Industry, 1968-1998, Master Dissertation, Jakarta, University of Indonesia, 2011.

Aminullah, E. and Adnan, R. S., "Resources of Innovation in Indonesian Automotive Industry the Role of University and Public Research Institution (PRI)", in Atsushi Sunami, PartarapongIntarakumnerd, A Comparative Study on the Role of University and PRI as External Resources for Firms' Innovation, ERIA Research Project Report 2010-10, ERIA, Jakarta, 2010, pp. 111-168.

Aminullah, E. and Adnan, Richardi S., A Comparative Study on the Role of University and PRI as External Resources for Firms' Innovation (Jakarta: ERIA Research Project Report, 2010).

Amsden, A., Asia's Next Giant: South Korea and Late Industrialization (NY: Oxford University Press, 1989).

Aswicahyono, B. and M. ChatibBasri, and Hal Hill, "How not to industrialize? Indonesia's Automotive Industry",
Bulletin of Indonesian Economic Studies, No. 36, Vol. 1,2003, pp. 209-241.

Aswicahyono, B. The Development of the Indonesian Automotive Industry, Jakarta, Center Strategy and International Study Working Paper, 1999.

Aswicahyono, H., Kelly Bird, Hal Hill, "Making Economic Policy in Weak, Democratic, Post-Crisis States: an Indonesian Case Study", World Development, No. 3, pp. 354-370.

Automotive Federation of Malaysia (AFM), "Submission of AFM on the Industrial Master Plan" ,The ASEAN Motor Industry in Economist Intelligence Unit (KL: EIU., 1984).

Biswajit Nag \&Saikat Banerjee \&RittwikChatterjee, Changing Features of the Automobile Industry in Asia: Comparison of Production, Trade and Market Structure in Selected Countries, Working Papers 3707, IDEAS, 2007.

CumingsBruce, The Origins and Development of the Northeast Asian Political Economy: Industrial Sectors, Product Cycles, and Political *Consequences," International Organization winter 1984, pp.1-40.

Buchanan, J. M., "Rent Seeking and Profit Seeking" in J. M. Buchanan, R. D. Tollison and G. Tullock (eds.), Toward a Theory of the Reat-Seeking Society (College Station: Texas A.\&M University Press, 1980 ) , pp. 3-15;

Bhagwati, DUP Activities and Economic Theory (Cambridge: Cambridge, 1982) .

Budiartie, G. and Primartantyo, U., "National Auto Still Way Ahead, says Gaikindo", Tempo, 04 January 2012,

Camilleri, J., "States, Markets and Civil Society in Asia Pacific", The Political Economy of the Asia-Pacific Region, Vol. 1, 2000, pp. 38-39.

Chalmer, I., Domestic Capital in the Revolution of Nationalist Auto 
Development Policy in Indonesia: from Instrumental to Structural Power, Murdoch University Asia Research Centre Working Paper, No. 30, 1994.

Dicken, P., Global Shift: Transforming the World Economy (London: Paul Chapman, 1998), p. 318.

Doner Richard F., Driving a Bargain: Automobile Industrialization and Japanese Firms in Southeast Asia (Berkeley: University of California Press, 1991).

Evans, P., Dependent Development: The Alliance of Multinational, State, and Local Capital in Brazil (N.Y.: Princeton University Press, 1979), pp. 32 54.

Events, P., "The State and Economic Transformation: Toward an Analysis of the Conditions Underlying Effective Intervention" in ThedaSkocopol, Bring the Sate Back In (Cambridge: Cambridge University Press, 1985).

Feith, H.,The Decline of Constitutional Democracy in Indonesia (Ithaca: Cornell University Press, 1962).

Fuangkajonsak, W., Industrial Policy Options for Developing Country: The Case of the Automotive Sector in Thailand \& Malaysia, Master of Arts in Law and Diplomacy Thesis, Tufts University, 2006.

Gerschenkron A., Economic Backwardness in Historical Perspective a Book of Essays (New York: Baker \& Taylor Books, 1962).

Gilpin, R., U.S. Power and the Multinational Corporation (Basic Books, New York, NY, 1975).

Gomez, Edmund T. and Jomo, K. S., Malaysia's Political Economy: Politics, Patronage and Profits (London: Cambridge University Press, 1999).

Gustafsson, F., The Greasy Palm: Malaysian Industrial Policy and the Palm Oil Industry, Master Thesis, Lund University, Sweden, 2006.

Crouch H., "Malaysia: Nither Authoritarian nor Democratic" in K. Hewison, R. Robison and G. Rodan(eds.), Southeast
Asia in the 1990`s:Authoritarianism ,Democracy and Capitalism (St. Leonards: Allen and Unwin,1993), pp. 133-158.

Haggard, Stephen M., "Business, Politics and Policy in East and Southeast Asia" in Henry S. Rowen, (ed.), Behind East Asian Growth: The Political and Social Foundations of Prosperity (London: Rutledge, 1997), pp. 81-82.

Ha-Joon Chang, The Political Economy of Industrial Policy (London: Macmillan, 1994).

Hansen, "The Motor Vehicle Industry", Bulletin of Indonesia Economic Studies, Vol. 7, No. 2, 1971, pp. 57-58.

Hasan, P., Korea: Problems and Issues in a Rapidly Growing Economy (Baltimore: The Johns Hopkins University Press, 1976).

Ho Khai Leong, Indigenizing the State: the New Economic Policy and Bumiputra State in Penunsular Malaysia, Ph. D. Diss., The Ohio State University, 1988.

Ito ,Keiko., Foreign Ownership and Productivity in the Indonesia Automotive Industry: Evidence from Establishment Data for 1990-1999, Kitayushu, Working Paper Series, Vol. 2002-25, 2002, The International Center for the Study of East Asian Development, 2002.

Jenkins, R., "The Political economy of industrial policy: Automobile Manufacture in the Newly Industrializing Countries", Cambridge Journal Economics, No. 15, 1995, pp. 625645.

Jenkins, R., Transnational Corporations and Uneven Development -Development $\mathcal{E}$ Underdevelopment (London: Rutledge, 1987).

Johnson, C., "Political Institutions and Economic Performance: A Comparative Analysis of the Government-business Relationship in Japan, South Korea, and 
Taiwan," in Frederic C. Deyo, ed., The Political Economy of the New Asian Industrialism (Ithaca, NY: Cornell University Press, 1987), pp. 136-164.

Johnson, C., MITI and the Japanese Miracle (Stanford: Stanford University Press, 1982).

Jomo, J. S., Rethinking the Role of Government Policy in Southeast Asia(Singapore: NUS Press, 2007).

Kelly, Robert E., "No 'Return to the State': Dependency and Developmental-ism against Neoliberalism," Development in Practice, Vol.18, No.3, June 2008, p. 322.

Kesavatana, W., Political Economy of Direct Foreign Investment in Thailand: A Case Study of the Automobile Industry, Ph.D. diss., University of Michigan, 1989.

Kohpaiboon, A., Thai Automotive Industry: Multinational Enterprises and Global Integration. ERTC Discussion Paper Faculty of Economics, Thammasat University 2007.

Kruger, A. O. "Government Failures in Development", Journal of Economic Perspectives, No. 4, Vol. 3, 1991, pp. 9-23.

Kumon S. and Rosovsky, H., The Political Economy of Japan: Cultural and Social Dynamics (Stanford, California: Stanford University Press, 1972), pp. 109-141.

Kuniko Fujita and Richard Child Hill, "Auto Industrialization in Southeast Asia: National Strategies and Local Development", ASEAN Economic Bulletin, Vol. 13, No. 3, 1997, p. 312-332.

Liddle, W., "The Politics of Shared Growth:

Some Indonesian Cases", Comparative Politics, Vol. 19, No. 2, January 1987, pp. 127-146.

Liddle, W., "The Relative Autonomy of the Third World Politician: Soeharto and Indonesian Economic Development in Comparative Perspective", International Studies Quarterly, Vol. 35, 1991, pp. 403427.

Lim, Nenham, "ASEAN Automotive Integration- Private Sector Perspective" paper present at The 8th APEC Automotive Dialogue, Bali Indonesia, 15-18 May 2006.

MacIntyre A., "The politics of finance in Indonesia: Command, confusion, and competition", in S. Haggard, C. H. Lee, and S. Maxfield, The Politics of Finance in Developing Countries(New York Cornell University Press, 1993), pp. 123-164.

MacIntyre, Andrew J., "Rethinking StateSociety Relations in New Order Indonesia: Challenges from the Business Sector" in A. Budiman (ed.) The State and Civil Society in Indonesia (Monash: Centre for Southeast Asian Studies \&Monash University Press, 1991).

Mai F., "Industrial Policies and Trade Liberalization? The Automotive Industry in Thailand and Malaysia", in KeijiOmura (ed.)The Deepening Economic Interdependence in the APEC Region, APEC Study Center (Singapore: Institute of Developing Economies, 1998).

Pangestu, M. and Habir, Ahmad D., "Trends and Prospects in Privatization and Deregulation in Indonesia", ASEAN Economic Bulletin, MARCH 1989, pp. 224-241.

Rock, Michael T. and Sheridan, M., "The Political Economy of Industrial Policy in Malaysia" in K. S. Jomo, Malaysian Industrial Policy (Singapore: NUS, 2006), pp. 179-181.

Rock, Michael T., "Reassessing the Effectiveness of Industrial Policy in Indonesia: Can the Neoliberals be Wrong?",World Development, Vol. 27, No. 4, 1999, pp. 691-704.

Soejachmoen, Moekti P., "Globalization and the Automotive Industry: Is Indonesia missing out?", Arndt-Corden Department of Economics Working Paper, Australian National University, 2011, pp. 41-42.

Soesastro, H., Government and Deregulation in Indonesia (Jakarta: Centre for Strategic and International Studies, 1989), pp. 
105-117.

Tan LiokEe, "Dongjiaozong and the Challenge to Cultural Hegemony" in Joel S. Kahn and Francis LohKokWah(eds.), Fragmented Vision: Culture and Politics in Contemporary Malaysia (Australia: Allen and Unwin, 1992).

Torii, T., "Changing the Manufacturing Sector, Reorganizing Automobile Assemblers, and Developing the Auto Component Industry under the New Economic Policy", The Developing Economies , XXIX. 1991, pp. 387-413.

Wad, P., Business Relations in Crisis? The Case off the National Auto Manufacturers in South Korea and Malaysia during the East Asian Crisis" Part III: The Malaysian Auto Industrial Networks in a Net holder Perspective (Copenhagen: Copenhagen Business School, 1999), Occasional Paper $102 \mathrm{DICM} / \mathrm{CBS}$.

Wad, P., Transforming Industrial Relations: the Case of the Malaysian Auto Industry, IIAS/IISGCLARA Working Paper, No. 12, Amsterdam, 2001.

Wade, R. H., “What Strategies Are Viable for Developing Countries Today? The World Trade Organization and the Shrinking of Development Space", Review of International Political Economy, Vol. 10, No. 4, 2003, pp. 621-644.

Wade, R., Governing the Market: Economy theory and the role of Government in East Asian Industrialization, (Princeton, New Jersey: Princeton University Press, 1990).

Witoelar, W., "Ancillary firm development in the motor vehicle industry in Indonesia", in K. Odaka, The Motor Vehicle Industry in Asia: A Study of Ancillary Firm Development (Singapore: Singapore University Press, 1983).

Yoshihara ,K., Building a Prosperous Southeast Asia: Moving from Ersatz to Echt Capitalism (New York: Routledge, 1998).

Ge-Chang Yu, "Indonesian domestic car then step journey," Asia Magazine, Vol 26, 2012.

Chong-Bo $\mathrm{Wu}$, "the Indonesian automobile industry, policies and prospects", Southeast Asia Studies, No. 3, 2011, pp. 50-52.

Zhenzhao Song, ASEAN's Political and Economic Development,(Taipei : WUNAN BOOK INC. ,1996).

Hsu Fu-Tian, "the East Asian financial crisis on the development of the ASEAN Free Trade Area Overview", invest in Southeast Asia bimonthly, No. 10, February 2002.

FanhanZeng, "Thailand and Malaysia Automobile Industry Development Policy", Industry newsletter, Vol 31, No. 2, 2001, pp. 17-22.

Jing leniency, "ASEAN industrial cooperation and the development direction," The Major National Policy Developments Quarterly, No.1, March 2001.

Wan-Ping Tai ,"ASEAN economic cooperation for political and economic impact of industrial policy: the case of Malaysia's automobile industry," AsiaPacific Research Forum, No. 42, December 2008, pp. 53-76.

Wan-WwnChu , “The Effects of Taiwan's Industrial Policy: A Preliminary Evaluation", Taiwan : A Radical Quarterly in Social Studies, No. 42 , June 2001 , pp. 67-117.

Wan-WwnChu , "Democratization and Economic Development The Unsuccessful Transformation of Taiwan's Developmental State", Taiwan: A Radical Quarterly in Social Studies, No. 84 , 2011 , pp. 243-288. 